\title{
Teaching Video NeuroImage: Dissociation of Abdominal Reflexes in Rheumatoid Atlantoaxial Subluxation
}

Igor Vilela Brum, MD, and Guilherme Diogo Silva, MD

Neurology ${ }^{\circledR}$ 2022;98:e211-e212. doi:10.1212/WNL.0000000000013007

Figure Spinal Cord Compression by Atlantoaxial Subluxation and Retrodental Pannus

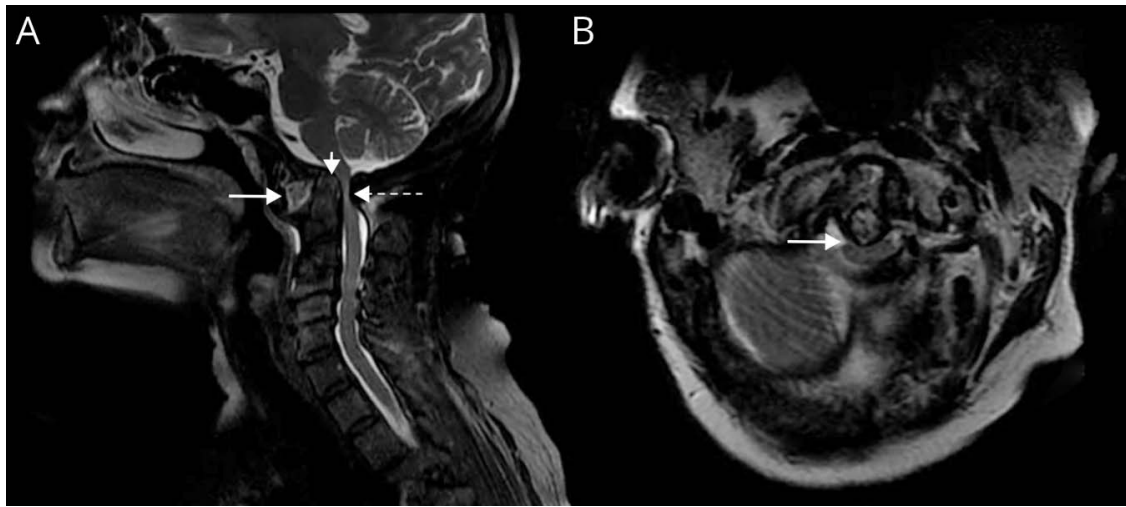

T2-weighted sagittal (A) spine MRI showing spinal cord compression and high signal intensity at the level of C1-C2 (dashed arrow) because of anterior subluxation of the atlas (solid arrow) and retrodental pannus (small arrow) in a patient with rheumatoid arthritis. T2-weighted axial (B) image confirms spinal cord compression by atlantoaxial subluxation (arrow, B).

A 59-year-old woman with rheumatoid arthritis presented with progressive gait difficulties and electric shock-like pain triggered by neck flexion (Lhermitte sign) for more than 6 months. On examination, she had hyperreflexia in the 4 limbs and brisk deep abdominal reflexes with absent superficial abdominal reflexes (reflex dissociation) (Video 1). MRI showed spinal cord compression resulting from anterior subluxation of the atlas and retrodental pannus (synovial tissue proliferation) (Figure). Superficial abdominal reflexes may be absent in $20 \%$ of normal individuals. ${ }^{1}$ However, the dissociation of abdominal reflexes suggests an upper motor neuron lesion above the T6 spinal segment. ${ }^{2}$

\section{Study Funding}

The authors report no targeted funding.

\section{Disclosure}

I.V. Brum reports no disclosures relevant to the manuscript; G.D. Silva reports no disclosures relevant to the manuscript. Go to Neurology.org/ $\mathrm{N}$ for full disclosures.
Correspondence

Dr. Brum

igor.brum@hc.fm.usp.br
MORE ONLINE

\section{Teaching slides}

links.lww.com/WNL/

B633

Video 
Appendix Authors

\begin{tabular}{lll}
\hline Name & Location & Contribution \\
\hline $\begin{array}{l}\text { Igor Vilela } \\
\text { Brum, MD }\end{array}$ & $\begin{array}{l}\text { Department of Neurology, } \\
\text { University of Sao Paulo, } \\
\text { Brazil }\end{array}$ & $\begin{array}{l}\text { Drafting/revision of the } \\
\text { manuscript for content, } \\
\text { including medical writing for } \\
\text { content, major role in the } \\
\text { acquisition of data, study } \\
\text { concept or design, and analysis } \\
\text { or interpretation of data }\end{array}$ \\
\hline $\begin{array}{l}\text { Guilherme } \\
\text { Diogo Silva, } \\
\text { MD }\end{array}$ & $\begin{array}{l}\text { Department of Neurology, } \\
\text { Bniversity of Sao Paulo, }\end{array}$ & $\begin{array}{l}\text { Drafting/revision of the } \\
\text { manuscript for content, } \\
\text { including medical writing for } \\
\text { content }\end{array}$ \\
\hline
\end{tabular}

\section{References}

1. Madonick MJ. Statistical control studies in neurology: 8. The cutaneous abdominal reflex. Neurology. 1957;7(7):459-465.

2. Teasdall RD, Van Den Ende H. A note on the deep abdominal reflex. J Neurol Neurosurg Psychiatry. 1982;45(4):382-383. 


\section{Neurology}

\section{Teaching Video NeuroImage: Dissociation of Abdominal Reflexes in Rheumatoid Atlantoaxial Subluxation \\ Igor Vilela Brum and Guilherme Diogo Silva \\ Neurology 2022;98;e211-e212 Published Online before print October 21, 2021}

DOI 10.1212/WNL.0000000000013007

This information is current as of October 21, 2021

\begin{tabular}{|c|c|}
\hline $\begin{array}{l}\text { Updated Information \& } \\
\text { Services }\end{array}$ & $\begin{array}{l}\text { including high resolution figures, can be found at: } \\
\text { http://n.neurology.org/content/98/2/e211.full }\end{array}$ \\
\hline References & $\begin{array}{l}\text { This article cites } 2 \text { articles, } 2 \text { of which you can access for free at: } \\
\text { http://n.neurology.org/content/98/2/e211.full\#ref-list-1 }\end{array}$ \\
\hline Subspecialty Collections & $\begin{array}{l}\text { This article, along with others on similar topics, appears in the } \\
\text { following collection(s): } \\
\text { All Spinal Cord } \\
\text { http://n.neurology.org/cgi/collection/all_spinal_cord } \\
\text { Clinical neurology examination } \\
\text { http://n.neurology.org/cgi/collection/clinical_neurology_examination } \\
\text { MRI } \\
\text { http://n.neurology.org/cgi/collection/mri }\end{array}$ \\
\hline Permissions \& Licensing & $\begin{array}{l}\text { Information about reproducing this article in parts (figures,tables) or in } \\
\text { its entirety can be found online at: } \\
\text { http://www.neurology.org/about/about_the_journal\#permissions }\end{array}$ \\
\hline Reprints & $\begin{array}{l}\text { Information about ordering reprints can be found online: } \\
\text { http://n.neurology.org/subscribers/advertise }\end{array}$ \\
\hline
\end{tabular}

Neurology ${ }^{\circledR}$ is the official journal of the American Academy of Neurology. Published continuously since 1951, it is now a weekly with 48 issues per year. Copyright () 2021 American Academy of Neurology. All rights reserved. Print ISSN: 0028-3878. Online ISSN: 1526-632X.

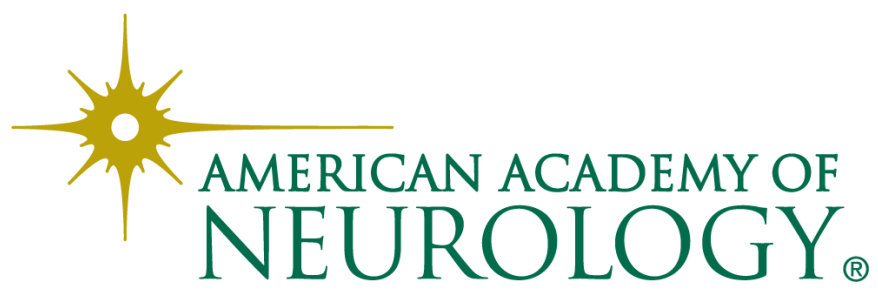

